GLOSSARY

Places and health

H V Z Tunstall, M Shaw, D Dorling

J Epidemiol Community Health 2004;58:6-10

This glossary aims to provide readers with some key conceptual tools with which to address the issue of place and health; it is hoped that it will provoke thought and debate on the range of ways that places are connected to health.

See end of article for authors' affiliations ......................

Correspondence to: Professor D Dorling, Department of Geography University of Sheffield. Sheffield S10 2TN, UK. daniel.dorling@ sheffield ac uk

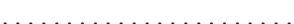

$\mathrm{T}$ he purpose of this glossary is to discuss some of the ways in which place is related to health and how the concept of place has come to be defined and used in the study of health. We also consider how a broader and deeper understanding of place could be used in the study of health, thereby contributing to the conceptual debate. Places can be defined in many ways. Often it is their distinguishing characteristics-what sets them apart-which receives most attention. However, such an approach discounts what matters most about places-that is, how they are connected, to each other, and how they relate to other concepts relevant to understanding public health. The "definitions" presented in this glossary are thus an attempt to advance the concept of place in health, by exploring the link between place and other concepts, and to suggest where current thinking may have become stuck in particular places.

\section{HEALTH AND PLACE(S)}

In this section we briefly review some of the conventional ways in which place has been shown to be related to health and some of the methodological dilemmas in this area. Research from geography, epidemiology, and public health shows that where people live significantly affects their health outcomes. This can include such dimensions as global differences in healthy life expectancy, ${ }^{1}$ comparisons of disease rates across regions of the world, ${ }^{23}$ reports of within country variations in health outcomes, ${ }^{4-6}$ and variations in life chances and health outcomes within specific localities. ${ }^{78}$ Spatial considerations have traditionally covered the spread of infectious diseases $^{9}$ and proximity to potentially health damaging sites ${ }^{10-15}$ but in recent years have increasingly focused upon chronic diseases. ${ }^{16}{ }^{17}$

Quantitative geographical analysis of health has, however, long been criticised for methodological uncertainties suggested by issues of ecological fallacy, scale, the modifiable areal unit problem, and spatial autocorrelation. ${ }^{18-21}$ The ecological fallacy refers to the inference of group or area characteristics as individual (for example, assuming that in an area of high levels of illness containing many teenage mothers, that teenage mothers in that area will necessarily have high levels of illness). Issues of scale relate to the size of the units of analysis (whether local, regional, national, etc); while the modifiable areal unit problem refers to the choice of such units and how this reflects the relations observed. Spatial autocorrelation simply refers to that fact that many phenomena are spatially dependentunemployed people tend to be located near other unemployed people. These issues can thus be summarised as follows: making assumptions about people given their locality, not being concerned about the size of places in studies, or how places are constructed, or how they are interrelated.

More recently methodological debate has been provoked by a tranche of research that has sought to separate out "area effects" from those of aggregate population characteristics, ${ }^{22}$ often using the statistical technique of multi-level modelling. ${ }^{23-27}$ Characteristics of places are typically distilled in this type of analysis to a few limited variables; "area effects" are sometimes not found ${ }^{2829}$ and when found, tend to be small..$^{30}$ This analysis of "area effects" frequently fails to conceptualise what type of place is meant by "area"-home, street, neighbourhood, workspace, society or indeed what is meant by "effects" - what are the causal pathways by which place effects health? Instead place is frequently considered a black box (of variable sizes and shapes) in which unidentified "nonindividual" processes take place. ${ }^{31}$ However, the connection of health and place can perhaps be enhanced by applying a broader and more nuanced conceptual toolkit.

\section{PLACES AND SPACES}

It is crucial to grasp the difference between place and space. A "space" describes where a location is while a "place" describes what a location is. Place is to space as history is to time and home is to house. Place is the interpretation of space and the study of places, through human geography, can be as rich as the study of time through social history. In public health many studies refer to where people live (or work, or die) in space, omitting any consideration of "place". Such reductionism is useful in terms of study design (and mapping), but has the effect of masking the complexity of meaning and processes associated with place. A range of studies within the new "health geography" ${ }^{32}$ have considered place and health in more depth. For instance research has considered the role of place in creating "the body", identity, mental illness, disability, and care. $^{34-37}$ These studies typically contain an intense analysis at the micro scale, intricately describing and theorising the meaning of place. Just as places are argued to create the nature of people and their health (living in a highly 
polluted environment can severely affect the health of the people living there) so too places are the creations of people (and occasionally conceptions of health and healing are a fundamental part of this formative process, as has been the case with Lourdes in France). This inseparability of people and places often leads to confusion over the direction of causation and claims of reverse causation when the two are artificially separated.

\section{PLACES AND CLASSES}

One of the ways in which we characterise places is by the type of people who live there-almost as if we view places as containers for categories of people. To consider social inequalities in health we look at places in terms of the proportion of their population in social classes, ${ }^{38}{ }^{39}$ and by other measures of socioeconomic status based upon area income and deprivation. ${ }^{40-42}$ Statistical models are used to analyse the relative effects of the "composition" and "context" of areas. ${ }^{23-27}$ These models "control" for such "compositional" factors as if the effects of class and poverty on health can be 'held constant' in different places. In such models it is assumed that part of the variation in health observed between places can be attributed to the characteristics of the people living in those places and part to the effects of those places on peoples' health. Although a useful means of supposedly removing most of the apparent variation between the mortality or morbidity rates of places, the results of analysis are entirely dependent on the definition of "individual" level and "area" level characteristics. Understanding can be greatly improved when recognising the contribution that place makes to class (rather than class makes to place). As Macintyre and Ellaway ${ }^{43}$ argue "the distinction between people and places, composition and context, is somewhat artificial. People make places, and places make people". The proportion of people in each class is dependent upon the place in which they live in. For example, a mining town will have many miners. Places make and mould people through their histories and geographies- the opening of the mine would have been dependent on a point in time when there was enough capital available, and the physical geography of the coal seams that needed to be running beneath it for the mine to be possible. Reducing poor health in a mining town to a largely "composition effect" is not only simplistic, but also ignores what helps create composition effects in the first place (manual labourers, such as miners, often do work that induces poor health).

The problems of a methodology that attempts to control for the proportions of social groups composing areas is also suggested by studies of the relation between "race" and health that have considered "racial segregation". Such analysis, predominantly completed in the USA, suggests that characteristics of the racial composition of places are related to the causal processes that create health outcomes. Racial segregation or racial isolation of "black" populations is associated with higher rates of mortality within these populations. ${ }^{44-46}$ Racial segregation is likely not only to play a significant part in social mechanisms determining access to education, employment, and other factors affecting health within these places but also to reflect a history of racial inequality and racial differences in patterns of migration between places.$^{47}$ Hence using "race" as a catch all category to "control for" factors such as culture, religion, heritage, identity, and power relations belies the connection between class, race, and place.

\section{PLACES AND CAPITALS}

Social capital ${ }^{48-52}$ has become a favoured explanation for area differences in health ${ }^{53}$ that may be termed contextual effects or, put more crudely, the residuals left after the regression analysis has removed supposed compositional effects. Places where fewer people are ill than would be expected within these analyses are deemed to have high levels of social capital identified by researchers as being some kind of intangible community force. Critiques of the labelling of models' residuals as social capital are beginning to emerge, however. ${ }^{55}{ }^{56}$ One key strand of criticism suggests that it is difficult to meaningfully divide the social capital of places from their material capital. It is within places that the residual of material capital is laid down. The developed world is developed because under its streets lie the sewers built from the capital raised during earlier times (often from what is now the "less developed" world). Its homes, public buildings, and roads are the embodiment of past capital accumulation and the bodies of its peoples and communities reflect the collective benefits of material wealth accrued over time variously in each place (place histories). A methodological critique of work in this area is that pre-existing questionnaire items collected at the individual level are often retrospectively selected and aggregated as if representative of some concept of social capital area at the area level (this is an example of the "atomistic fallacy" where the attributes of individuals are assumed to apply to areas).

\section{PLACES AND SCALES}

Perception of the character of the relation between health and place seems to vary with the type and, in particular, the scale of place. While some multi-level modelling of "area effects" on health have included places of different scales ${ }^{57} 58$ the significance of scale has been little theorised. ${ }^{59}$ Analyses of the relative effects of area context and composition upon health have frequently been carried out using small scale administrative data such as wards and census tracts but have less commonly been applied to large scale comparisons of, for example, countries. ${ }^{30}$ International variations in health outcomes appear to be implicitly accepted as legitimate "area effects". So while it has been argued that the health of small areas are mostly the product of the individuals that compose them, the health of nations appear to be widely assumed to be the product of their history, culture, capital, economics, ethnicity, religion, and other social factors. Different types and scales of place must play different parts in health but these relations have not been clarified conceptually or empirically. Spatial scale matters, but is often ignored as an issue in research on places and health.

\section{PLACES AND TIMES}

The importance of "history" to health has been emphasised by life course epidemiology, an expanding area of research and evidence. ${ }^{6061}$ The term "life course" refers to the accumulation and embodiment of factors influencing the health of individuals and social groups, from the pre-natal period, through infancy and childhood, and across adulthood. ${ }^{62-67}$ However, these studies prioritise the study of time at the expense of exploring dimensions of place. Conversely, studies that consider place are most commonly cross sectional; many of those health studies that are longitudinal typically contain samples from only a limited number of places and do not contain enough detail to be able to consider the role of place. However, just as times (events, eras,

\section{Policy implications}

- No person is an island because it is through places that their lives are lived and places are peoples, histories, classes, capital and ... health. 
cohorts) differ so too places are distinct and have distinct histories. Too often our limitations (of data resources and mental concentration) mean that place and history are dislocated; few studies consider the life course of places and how place histories influence life courses. ${ }^{68-73}$ The working definition of place in research on health could be widened to include peoples' places in time as well as space to counteract the reductionism of the biomedical model.

\section{PLACES AND MIGRATIONS}

The study of population movements between places over time is a further conceptual dimension that the consideration of place can contribute to the understanding of health. Analysis of the impact on health of migration has traditionally focused upon modelling the role of population movements in the spread of infectious diseases. ${ }^{74-76}$ More recently longitudinal analysis of "selective" migration has contributed to the understanding of inequalities in mortality between places. ${ }^{77} 78$ The consideration of population movements between places also has an important part to play in understanding the significance of genetics to health. The influence of genes upon health has been one of the greatest points of interest in health research in recent decades but this work has generally had little association with geography, despite the fact that differences in population groups' genetics are largely the product of geography. ${ }^{79}$ The places in which our ancestors lived shape the characteristics of our genetic inheritance. Our health is therefore affected not only by the places we have lived during our life course and where our parents lived but where our ancestors lived thousands of years ago.

While ancient geographical migrations largely explain the genetic differences found today between population groups, very recent geographical migration permits consideration of genetically similar populations living in different places and so can be used to critique genetic explanations of "racial" differences in health between populations. For example, there have been a number of studies finding differences in blood pressure in "black" and "white" populations in the $\mathrm{USA}^{80-82}$ and it has been suggested that hypertension in "black" populations are genetic in cause. ${ }^{83}$ However, a review of studies comparing diurnal blood pressure in "black" and "white" populations that included analysis of places in USA and UK found the relation between "race" and blood pressure varied between countries. ${ }^{84}$

\section{CONCLUSION}

To move current debates in public health forward it may be useful to view places as more than the sum of the current human populations living and dying within them. Places form people as much as places are formed from peoples. Places have and are histories; they have their own life histories made up of (and strongly influencing) the millions of points at which the life histories of individuals and families pass through each place. Places exist only in relation to one another. Their influence on health and how they in turn are influenced by health depends on those links. Capital is accumulated in places. This can be seen most clearly in the physical fabric of places and the physical fabric is the most obvious and immediate direct determinate of public health. From the quality of sewers and fresh water courses, to the decency of housing to help people build stable homes, to the links which are both physically and socially built to other places, and to the grand buildings constructed to celebrate collective wealth-ranging from cathedrals to palaces to hospitals-places are much more than the sum of their parts. They are more than useful collecting units to attempt to measure something you would rather measure at the (so called) individual level. No person is an island because it is through places that their lives are lived and places are peoples, histories, classes, capital, and ... health.

This glossary has presented arguments against the impulse within health research to ignore or abstract place and for considering place not as "context" but within context. In contemporary public health and epidemiology the study or inclusion of place is often seen as an academic back-water. It is true that the first Choropleth maps of disease ${ }^{85}$ were drawn by inmates of a lunatic asylum. It is true that you can eliminate the vast majority of apparent spatial variations in health by defining more and more characteristics in a model, such as social class, occupation, education, ethnicity, etc, as being purely "individual" and unrelated to place. But it is also true you are largely healthy because of where and when you were born. If you suffer from poor health that is mitigated by your geography and the health services you receive because of it. And, all this is true because of what happened in these places before you passed through them. Because place is in everything-in health, through space, through time, in genes, in class and in how capital is expressed-its omnipresence makes it all too often easy to ignore. There was, of course, a time when the importance of place to health was more obvious ${ }^{86}$ :

"In the dry hills the dead don't smell bad; don't really smell at all; or sometimes they smell of the thyme and savory in which they are lying, always in very noble postures because they have died facing a grand landscape. Sight of the free horizon, generally periwinkle-blue, gives the muscles a fluidity that makes them unclench after death. He had observed that in the pine groves, where the scent of the resin joins with the sun to create an atmosphere like an oven, the corpses he encountered (one of them was a game keeper's) had above all the mal du siècle: a certain nonchalance of style and melancholy in their attitudes, a look of ennui, a sort of well-bred contempt. The woods above Palette, when you approach the rocky spurs of Sainte-Victoire, look out over a billowing of hills, a network of little plains, valleys, copses, vistas, and aqueducts as Roman as could be. You are forced to think of the geese of the Capital, of the Cimbri wrapped in the Nordic mists like processionary caterpillars in their cotton nests. A man dying, especially of cholera and shaken by electric discharges of pain, no longer sees the present, he sees the past and the future through a magnifying glass for several long minutes."

(An outbreak of cholera in 1830s Provence, as described by Jean Giono.)

\section{Authors' affiliations}

H V Z Tunstall, Research Unit In Health, Behaviour and Change, University of Edinburgh Medical School, Edinburgh, UK

M Shaw, Department of Social Medicine, University of Bristol, Bristol, UK D Dorling, Department of Geography, University of Sheffield, Sheffield, UK

\section{REFERENCES}

1 WHO. The world health report. Geneva: WHO, 2002.

2 WHO. Atlas of mortality in Europe: subnational patterns, 1980/1981 and 1990/1991. Geneva: WHO, 1997.

3 Shaw M, Orford S, Brimblecombe $N$, et al. Widening inequality in mortality between 160 regions of 15 countries of the European Union. Soc Sci Med 2000;50:1047-58.

4 Howe GM. Does it matter where I live? Transactions of the Institute of British Geographers 1986;11:387-414.

5 Griffiths C, Fitzpatrick J. Geographic variations in health, (DS no 16). London: HMSO, 2001.

6 Muelleman RL, Walker RA, Edney JA. Motor vehicle deaths: a rural epidemic. J Trauma 1993:35:717-19. 
7 Ellaway A, Macintyre S, Kearns A. Perceptions of place and health in socially contrasting neighbourhoods. Urban Studies 2002;38:2299-316.

8 Phillimore P, Morris D. Discrepant legacies: premature mortality in two industrial towns. Soc Sci Med 1991;33:139-52.

9 Haggett P. The geographical structure of epidemics. Oxford: Clarendon Press, 2000.

10 Snow J. On the mode of communication of cholera. New York: Harvard University Press, 1855. [Reprinted 1936].

11 Pocock SJ, Cook DG, Shaper AG. Analysing geographic variation in cardiovascular mortality. Journal of the Royal Statistical Society Series A 1982;145:351-41.

12 Bailey AJ, Sargent J, Blake M. A tale of two counties: childhood lead poisoning, industrialization, and abatement in New England. Economic Geography 1998;extra issue:96-111.

13 Craft AW, Openshaw S, Birch J. Apparent clusters of childhood lymphoid malignancy in Northern England. Lancet 1984;ii:96-7.

14 Parker L, Pearce MS, Dickinson HO, et al. Stillbirths among offspring of male radiation workers at Sellafield nuclear reprocessing plant. Lancet 1999;354:1047-54

15 Luginaah IN, Taylor SM, Elliott SJ, et al. A longitudinal study of the health impacts of a petroleum refinery. Soc Sci Med 2000;50:1155-66.

16 Diez-Roux AV, Nieto FJ, Muntaner C, et al. Neighborhood environments and coronary heart disease: a multilevel analysis. Am J Epidemiol 1997; 156:48-53

17 Davey Smith G, Hart C, Watt G, et al. Individual social class, area-based deprivation, cardiovascular diseases risk factors, and mortality: the Renfrew and Paisley study. J Epidemiol Community Health 1998;52:399-405.

18 Cliff AD, Ord JK. Spatial processes-models and applications. London: Pion, 1981.

19 Gatrell A, Löyłönen M, eds. GIS and health. London: Taylor and Francis, 1998.

20 Openshaw S. A geographical solution to scale and aggregation problems in region-building, partitioning and spatial modelling. Transactions of the Institute of British Geographers 1997;new series 2:459-72.

21 Openshaw S. The modifiable areal unit problem. Norwich: Geo Abstracts, 1984.

22 Macintyre S, Maciver S, Sooman A. Area, class and health: Should we be focussing on places or people? Journal of Social Policy 1993;22:213-34.

23 Diez Roux AV. A glossary of multilevel analysis. J Epidemiol Community Health 2002;56:588-94.

24 Diez Roux AV. The examination of neighborhood effects on health: conceptual and methodological issues related to the presence of multiple levels of organization. In: Kawachi I, Berkman LF, eds. Neighborhoods and health. New York: Oxford University Press, 2003:45-64.

25 Duncan C, Jones K, Moon G. Context, composition and heterogeneity: using multilevel models in health research. Soc Sci Med 1998:42:817-30.

26 Duncan C, Jones K, Moon G. Health-related behaviour in context: a multilevel modelling approach. Soc Sci Med 1996;42:817-30.

27 Subramanian SV, Jones K, Duncan C. Multilevel methods for public health research. In: Kawachi I, Berkman LF, eds. Neighborhoods and health. New York: Oxford University Press, 2003:65-111.

28 Slogget A, Joshi $\mathrm{H}$. Higher mortality in deprived areas: community or personal disadvantage? BMJ 1994;309:1470-4

29 Davey Smith G, Shipley M, Hole D, et al. Explaining male mortality differentials between the west of Scotland and the south of England. [Abstract]. J Epidemiol Community Health 1995;49:541.

30 Pickett KE, Pearl M. Multilevel analysis of neighbourhood socioeconomic context and health outcomes: a critical review. J Epidemiol Community Health 2001;55:111-22.

31 Macintyre S, Ellaway A, Cummins S. Place effects on health: how can we conceptualise, operationalise and measure them? Soc Sci Med 2002;55:125-39.

32 Earickson R. Health geography: style and paradigms. Soc Sci Med 2000:50:457-8.

33 Kearns R, Moon G. From medical to health geography: novelty, place and theory after a decade of change. Progress in Human Geography 2002;26:605-25.

34 Butler R, Parr H. Mind and body spaces: geographies of illness, impairment and disability. London: Routledge, 1999.

35 Kearns RA, Gesler WM. Putting health into place; landscape, identity and wellbeing. New York: Syracruse University Press, 1998.

36 Dyck I. Hidden geographies: The changing lifeworlds of women with disabilities. Soc Sci Med 1995:40:307-20.

37 Parr H. Medical geography: care and caring. Progress in Human Geography 2003;27:212-21.

38 Mitchell R, Dorling D, Shaw M. Inequalities in life and death: What if Britain were more equal? London: Joseph Rowntree Foundation, 2000.

39 Krieger N. Overcoming the absence of socioeconomic data in medical records: validation and application of census-based methodology. Am J Public Health 1992;82:703-10.

40 Stafford M, Marmot M. Neighbourhood deprivation and health: does it affect us all equally? Int J Epidemiol 2003;32:357-66.

41 Anderson R, Sorlie P, Backlund E, et al. Mortality effects of community economic status. Epidemiology 1997;8:42-7.

42 Davey Smith G, Hart G, Watt G. Individual social class, area-based deprivation, cardiovascular disease risk factors, and mortality: the Renfrew and Paisley study. J Epidemiol Community Health 1998;52:399-405.

43 Macintyre S, Ellaway A. Neighbourhood and health: an overview. In: Kawachi I, Berkman LF, eds. Neighborhoods and health. New York: Oxford University Press, 2003:26.
44 Acevedo-Garcia D, Lochner K A. Residential segregation and health. In: Kawachi I, Berkman LF, eds. Neighborhoods and health. New York: Oxford University Press, 2003:265-87.

45 Jackson SA, Anderson RT, Johnson NJ, et al. The relation of residential segregation to all-cause mortality: a study in black and white. Am J Public Health 2000;90:615-17.

46 Hart KD, Kunitz SJ, Sell RR, et al. Metropolitan governance, residential segregation, and mortality among African Americans. Am J Public Health 1998:88:434-8

47 Williams DR, Collins $C$. Racial residential segregation: a fundamental cause of racial disparities in health. Public Health Rep 2001;116:404-16.

48 Bourdieu P. The forms of capital. In: Richardson JG, ed. Handbook of theory and research for the sociology of education. New York: Greenwood, 1985:241-58

49 Coleman JS. Foundation of social theory. Cambridge, MA: Harvard University Press, 1990.

50 Putnam RD, Leonardi R, Nanetti RY. Making democracy work. Princeton, NJ: Princeton University Press, 1993

51 Putnam RD. Bowling alone: America's decline in social capital. Journal of Democracy 1995:6:65-78.

52 Mohan G, Mohan J. Placing social capital. Progress in Human Geography 2002;26:191-210

53 Mustard JF. Health and social capital. In: Blane D, Brunner E, Wilkinson R, eds. Health and social organisation. London: Routledge, 1996:303-13.

54 Kawachi I, Kennedy BP, Prothrow-Stith D. Social capital, income inequality, and mortality. Am J Public Health 1997;87:1491-8.

55 Muntaner C, Lynch J. Social capital, class gender and race conflict, and population health: an essay review of Bowling alone's implications for social epidemiology. Int J Epidemiol 2002;31:261-7.

56 Pearce N, Davey Smith G. Is social capital the key to inequalities in health? Am J Public Health 2003;93:122-9.

57 Jones K, Duncan C. Individuals and their ecologies: analysing the geography of chronic illness within a multilevel modelling framework. Health and Place 1995; 1:27-40.

58 Cubbin C, Pickle LW, Fingerhut L. Social context and geographic patterns of homicide among US black and white males. Am J Public Health 2000:90:579-87.

59 Mitchell R, Gleave S, Bartley M, et al. Do attitude and area influence health? A multilevel approach to health inequalties. Health and Place 2000;6:67-80.

60 Kuh D, Ben-Shlomo Y, eds. A life course approach to chronic disease epidemiology: tracing the origins of ill-health from early to adult life. Oxford: Oxford Medical Publications, 1997.

61 Ben-Shlomo Y, Kuh DA. Life course approach to chronic disease epidemiology: conceptual models, empirical challenges and interdisciplinary perspectives. Int J Epidemiol 2002;2:285-93.

62 Barker DJ. Fetal programming of coronary heart disease. Trends in Endocrinology and Metabolism 2002;13:364-8

63 Hertzman C, Weins M. Child development and long-term outcome: a population health perspective and summary of successful interventions. Soc Sci Med 1996;43:1083-95.

64 Lundberg $\mathrm{O}$. Childhood conditions, sense of coherence, social class and adult ill health: exploring their theoretical and empirical relations. Soc Sci Med 1997:44:821-31.

65 Mheen H van de, Stronks K, Bos J van den, et al. The contribution of childhood environment to the explanation of socio-economic inequalities in health in adult life: A retrospective study. Soc Sci Med 1997:44:13-24.

66 Rahkonen O, Lahelma E, Huuhka M. Past or present? Childhood living conditions and current socioeconomic status as determinants of adult health. Soc Sci Med 1997;44:327-36.

67 Wadsworth MEJ. Health inequalities in the life course perspective. Soc Sci Med 1997:44:859-69.

68 Braudel F. The Mediterranean in the ancient world [Text edited by R de Ayala and P Braudel; translated from the French by S Reynolds]. London: Allen Lane, 2001.

69 Braudel F. A history of civilizations [Translated by R Mayne]. London: Allen Lane, 1994.

70 Wallerstein I. The modern world-system, Vol 1. Capitalist agriculture and the origins of the European world-economy in the sixteenth century. New York: Academic Press, 1974

71 Marx K. Capital: a critique of political economy. London: Penguin, 1990.

72 Engels F. The condition of the working class in England. Harmondsworth: Penguin Books, 1997:1845.

73 Foucault $M$. The birth of the clinic : an archaeology of medical perception [Translated from the French by A M Sheridan Smith]. London: Tavistock, 1973.

74 Baroyan OV, Rvacher LA. Deterministic epidemic models for a territory with a transport network. Kibernetika 1967:3:67-74.

75 Cliff AD, Haggett P, Ord JK. Spatial aspects of influenza epidemics. London: Pion, 1986.

76 Longini IM Jr, Fine PEM, Thacker SB. Predicting the global spread of new infectious agents. Am J Epidemiol 1986;123:383-91.

77 Brimblecombe N, Dorling D, Shaw M. Mortality and migration in Britainfirst results from the British household panel survey. Soc Sci Med 1999:49:981-8

78 Brimblecombe N, Dorling D, Shaw M. Migration and geographical inequalities in health in Britain: an exploration of the lifetime socio-economic characteristics of migrants. Soc Sci Med 2000;50:861-78.

79 Templeton A. Human races: a genetic and evolutionary perspective. American Anthropologist 1998; 100:632-50. 
80 Belsha CW, Spencer HJ, Berry PL, et al. Diurnal blood pressure patterns in normotensive and hypertensive children and adolescents. J Hum Hypertens 1997;11:801-6.

81 Gretler DD, Fumo MT, Nelson KS, et al. Ethnic differences in circadian hemodynamic profile. Am J Hypertens 1994;7:7-14.

82 Hebert LA, Agarwai G, Ladson-Wofford SE, et al. Nocturnal blood pressure in treated hypertensive African Americans compared to treated European Americans. Am J Soc Nephrol 1996;7:2130-4.

83 Osei K, Schuster DO. Effects of race and ethnicity on insulin sensitivity, blood pressure, and heart rate in three ethnic populations: comparative studies in African-Americans, African immigrants (Ghanians), and white Americans using ambulatory bolld pressure monitoring. Am J Hyperts 1996;9:943-53

84 Profant J, Dimsdale JE. Race and diurnal blood pressure patterns: A review and meta-analysis. Hypertension 1999;33:1099-104.

85 Cliff AD, Haggett $P$, Smallman-Raynor $M$. Detecting space-time patterns in geocoded disease data: cholera in London, 1854 and measles in the United States, 1962-65. In: Gierl L, Cliff AD, Valleron AJ, et al, eds. GEOMED 1997 proceedings of the international workshop on geomedical systems. Stuttgart: Teubner Verlag, 1998:13-42.

86 Giono J. The horseman on the roof [1995 edn]. London: Harvill Press, 1951:315.

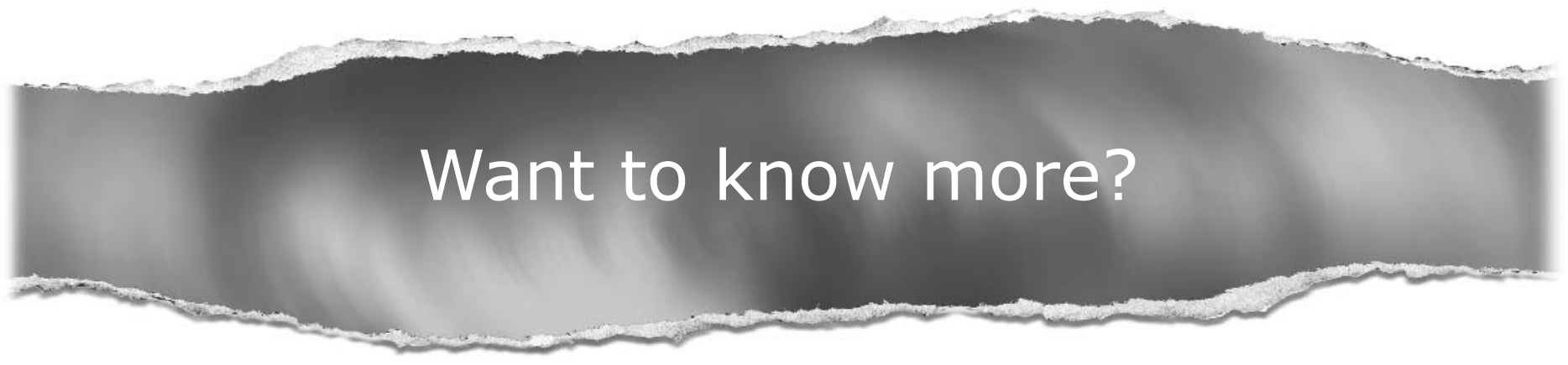

Data supplements

Limited space in printed journals means that interesting data and other material are often edited out of articles; however, limitless cyberspace means that we can include this information online.

Look out for additional tables, references, illustrations.

\section{www.jech.com}

